\title{
HUBUNGAN UMUR DAN GRAVIDA DENGAN KELENGKAPAN IMUNISASI (TETANUS TOXOID) TT IBU HAMIL DI BPM DYAH WIDYA SUSILOWATI NGEMPLAK BOYOLALI
}

\author{
Anita Dewi Lieskusumastuti ${ }^{1}$, Catur Setyorini ${ }^{2}$ \\ Email: anitadelieska@stikesmus.ac.id \\ DIII Kebidanan STIKES Mamba'ul 'Ulum Surakarta \\ J1. Ringroad Utara Km.03 Tawangsari Mojosongo Jebres Surakarta \\ Telp (0271) 858172
}

\begin{abstract}
Abstrak
Tetanus pada ibu dan bayi merupakan penyebab kematian paling sering terjadi akibat persalinan dan penanganan tali pusat tidak bersih. Tetanus neonatorum dapat dicegah dengan imunisasi dan atau pelayanan persalinan dan pasca persalinan yang bersih. Cakupan imunisasi TT2 + ibu hamil secara nasional dari tahun 2002 - 2011 berfluktuasi. Faktor yang berhubungan dengan pelaksanaan imunisasi Tetanus pada ibu hamil berdasarkan hasil penelitian meliputi usia, pendidikan, pengetahuan, dukungan suami, sikap petugas kesehatan. Penelitian ini bertujuan untuk mengetahui hubungan umur, gravida dan pendidikan dengan kelengkapan imunisasi TT pada ibu hamil.

Desain penelitian ini survey analitik dengan pendekatan potong lintang. Alat ukur kuesioner. Teknik pengambilan sampel adalah accidental sampling. Uji statistik analisis univariat menggunakan distribusi frekuensi, analisis bivariat menggunakan uji Chi Square dan analisis multivariat menggunakan Regresi Logistik Binary.

Hasil distribusi frekuensi responden diketahui sebagian besar berumur 20-35 tahun sebanyak 36 responden (72\%), Primigravida sebanyak 25 responden (50\%), Pendidikan Menengah sebanyak 30 responden (60\%) dan kelengkapan imunisasi TT sebagian besar tidak lengkap sebanyak 27 responden (54\%). Hasil uji chi square yang menunjukkan ada hubungan dengan kelengkapan imunisasi TT adalah variabel umur $(\mathrm{p}=0,004)$, dan gravida $(\mathrm{p}=0,000)$, sedangkan yang tidak ada hubungan adalah variabel pendidikan $(\mathrm{p}=0,192)$. Hasil uji regresi logistik menunjukkan ada hubungan signifikan secara simultan umur, gravida dan pendidikan terhadap Kelengkapan imunisasi TT dengan nilai Sig $0,000<$ alpha 0,05 . Nilai Nagelkerke $R$ Square sebesar 0,773 yang menunjukkan bahwa kemampuan variabel umur, gravida dan pendidikan dalam menjelaskan Kelengkapan imunisasi TT adalah sebesar 77,8\%, sedangkan sisanya sebesar 22\% dijelaskan oleh variabel lain di luar model yang menjelaskan variabel dependen. Kesimpulan ada ada hubungan signifikan secara simultan umur, gravida dan pendidikan terhadap Kelengkapan imunisasi TT.
\end{abstract}

Kata kunci: Umur, Gravida, Pendidikan, Kelengkapan Imunisasi Tetanus Toxoid

\section{Pendahuluan}

Tetanus pada ibu dan bayi merupakan penyebab kematian paling sering terjadi akibat persalinan dan penanganan tali pusat tidak bersih. Tetanus disebabkan oleh neurotoxin yang dihasilkan oleh Clostridium tetani pada luka anaerob (tertutup). Upaya pencegahan kematian akibat tetanus pada maternal dan neonatal saat ini mudah dilakukan dengan persalinan dan penanganan tali pusat yang higienis, serta imunisasi ibu dengan vaksin tetanus. $^{1}$

Strategi jangka panjang ETN (Eliminasi Tetanus Neonatorum) telah dilakukan melalui pelayanan dasar pada bayi serta BIAS (Bulan Imunisasi Anak Sekolah). Namun dengan hanya mengandalkan strategi ini kelompok yang terlindungi hanya usia dibawah 16 tahun sehingga pencapaian ETN akan menjadi lama. Untuk itu masih diperlukan imunisasi bagi wanita usia subur (WUS) termasuk ibu hamil, serta diperlukan akselerasi imunisasi TT untuk WUS khususnya di wilayah risiko tinggi sebagai strategi jangka pendek. ${ }^{1}$

Berdasarkan laporan surveilans kasus TN dapat diketahui bahwa jumlah kasus TN di Indonesia dari tahun 2007-2011 terjadi penurunan. Pada tahun 2007 jumlah kasus TN sebanyak 141 naik menjadi 198 kasus TN pada tahun 2008, namun jumlah kasus TN terus menurun sampai tahun 2011 menjadi 114 kasus TN. Angka KematianTN (case fatality rate) berdasarkan persentase neonatus meninggal diantara neonates terinfeksi tetanus dari tahun 2007-2011 berkisar antara 48\%-61\%. Namun walaupun 
terjadi penurun kasus dari tahun 20102011, Case fatality rate TN mengalami peningkatan hingga $61 \%$. Hal ini kemungkinan disebabkan oleh masalah tatalaksana penyakit akibat keterbatasan infrastruktur dan akses ke pelayanan kesehatan. $^{1}$

Imunisasi Tetanus Toxoid (TT) mempunyai manfaat utama khusus untuk ibu dan bayi, yakni untuk melindungi bayi baru lahir dan kemungkinan terjadinya Tetanus Neonatorum (kejang akibat infeksi tali pusat). Oleh karena itu, imunisasi TT harus diberikan melalui ibunya, karena janin belum dapat membentuk kekebalan sendiri. Pemberian imunisasi TT dianjurkan pada pasangan yang hendak menikah dan ibu hamil. ${ }^{2}$

Cakupan imunisasi TT2+ ibu hamil secara nasional dari tahun 2002 2011 berfluktuasi. Dari tahun $2002-$ 2007 terus menurun dari $68,1 \%-26 \%$. Dari tahun 2007 - 2009 meningkat dan kembali menurun sampai tahun 2011 menjadi $63,6 \%{ }^{1}$

Cakupan imunisasi TT pada wanita usia subur (WUS) dan ibu hamil di Kabupaten Boyolali pada tahun 2015 dilaporkan TT1 $(63,5 \%)$, TT2 $(58,6 \%)$, TT3 (21,6\%), TT4 (16,6\%), TT5 $(17,2 \%)$, TT2 $+(114,2 \%){ }^{2}$

Secara global hampir $14 \%$ penyebab kematian neonatus adalah tetanus neonatorum. Tetanus neonatorum bertanggung jawab terhadap $50 \%$ kematian neonatus yang disebabkan oleh penyakit yang dapat dicegah dengan imunisasi. Tetanus neonatorum dapat dicegah dengan imunisasi dan atau pelayanan persalinan dan pasca persalinan yang bersih. ${ }^{1}$

Beberapa hasil penelitian menunjukkan bahwa pemberian imunisasi tetanus toksoid 2 kali selama kehamilan dapat menurunkan kejadian tetanus neonatorum. Standar Pelayanan Antenatal terdiri dari enam tindakan, memberikan pelayanan imunisasi pada ibu hamil termasuk dalam tindakan pemeriksaan dan pemantauan antenatal. Tindakan yang lainnya meliputi identifikasi ibu hamil, palpasi abdominal, pengelolaan anemia pada kehamilan, pengelolaan dini hipertensi pada kehamilan dan persiapan persalinan. ${ }^{1,3}$

Faktor yang berhubungan dengan pelaksanaan imunisasi Tetanus pada ibu hamil berdasarkan hasil penelitian meliputi usia $(p=0,000)$, pendidikan $(p=0,002)$, pengetahuan $(p=0,035)$, dukungan suami $(\mathrm{p}=0,001)$, sikap petugas kesehatan $(p=0,001){ }^{4}$

Berdasarkan uraian diatas, penelitian ini bertujuan untuk mengetahui hubungan umur, gravida, pendidikan dengan kelengkapa status imunisasi Tetanus Toxoid (TT) pada ibu hamil di BPM Dyah Widya Susilowati Ngemplak Boyolali.

\section{Metode Penelitian}

Desain penelitian ini menggunakan rancangan survey analitik dengan pendekatan potong lintang.

Alat pengumpulan data menggunakan kuesioner.

Populasi penelitian ini adalah semua ibu hamil pada trimester 2 dan 3 yang melakukan pemeriksaan kehamilan di BPM Dyah Widya Susilowati dengan alamat Kismoyoso Ngemplak Boyolali pada bulan Maret-April 2018. Teknik pengambilan sampel adalah accidental sampling. Sampelnya adalah sebagian ibu hamil trimester 2 dan 3 yang melakukan pemeriksaan kehamilan di BPM Dyah Widya Susilowati dengan alamat Kismoyoso Ngemplak Boyolali pada bulan Maret-April 2018 yang ditemui peneliti pada saat pengambilan data sejumlah 50 responden.

Data yang telah terkumpul akan diolah dan dilakukan uji analisis. Uji statistik analisis univariat menggunakan distribusi frekuensi, analisis bivariat menggunakan uji Chi Square dan analisis multivariat menggunakan Regresi Logistik Binary. 


\section{Hasil dan Pembahasan}

Tabel 1. Distribusi Frekuensi Responden Berdasarkan Umur

\begin{tabular}{crcc}
\hline No & Umur & Jumlah & Persentase (\%) \\
\hline 1 & $<20$ tahun & 9 & 18.0 \\
2 & $20-35$ tahun & 36 & 72.0 \\
3 & $>35$ tahun & 5 & 10.0 \\
\hline \multicolumn{2}{l}{ Total } & 50 & 100.0 \\
\hline
\end{tabular}

Tabel 2. Distribusi Frekuensi Responden Berdasarkan Gravida

\begin{tabular}{clcc}
\hline No & \multicolumn{1}{c}{ Gravida } & Jumlah & Persentase (\%) \\
\hline 1 & Primigravida & 25 & 50.0 \\
2 & Multigravida & 20 & 40.0 \\
3 & Grandemultigravida & 5 & 10.0 \\
\hline \multicolumn{2}{l}{ Total } & 50 & 100.0 \\
\hline
\end{tabular}

Tabel 3. Distribusi Frekuensi Responden Berdasarkan Pendidikan

\begin{tabular}{llcc}
\hline No & \multicolumn{1}{c}{ Pendidikan } & Jumlah & Persentase (\%) \\
\hline 1 & Pendidikan Dasar & 15 & 30.0 \\
2 & Pendidikan & 30 & 60.0 \\
& Menengah & & \\
3 & Pendidikan Tinggi & 5 & 10.0 \\
\hline & Total & 50 & 100.0 \\
\hline
\end{tabular}

Tabel 4. Distribusi Frekuensi Responden Berdasarkan Kelengkapan Imunisasi TT

\begin{tabular}{crcc}
\hline No & Pendidikan & Jumlah & Persentase (\%) \\
\hline 1 & Ya Lengkap & 23 & 46.0 \\
2 & Tidak Lengkap & 27 & 54.0 \\
\hline & Total & 50 & 100.0 \\
\hline
\end{tabular}

Berdasarkan hasil distribusi frekuensi responden diketahui sebagian besar berumur 20-35 tahun sebanyak 36 responden (72\%), Primigravida sebanyak 25 responden (50\%), Pendidikan Menengah sebanyak 30 responden $(60 \%)$ dan kelengkapan imunisasi TT sebagian besar tidak lengkap sebanyak 27 responden (54\%).
Tabel 5. Hubungan Umur dengan Kelengkapan Imunisasi TT Pada Ibu Hamil di BPM Dyah Widya Susilowati Ngemplak Boyolali

\begin{tabular}{lcccc}
\hline \multirow{4}{*}{ Umur } & \multicolumn{2}{c}{ Kelengkapan } & & \\
& Imunisasi_TT & & \\
& Ya & Tidak & & P \\
\hline$<20$ tahun & 8 & 1 & 9 & 0,004 \\
& $(16 \%)$ & $(2 \%)$ & $(18 \%)$ & \\
$20-35$ & 15 & 21 & 36 & \\
tahun & $(30 \%)$ & $(42 \%)$ & $(72 \%)$ & \\
$>35$ tahun & $0(0 \%)$ & 5 & 5 & \\
& & $(10 \%)$ & $(10 \%)$ & \\
\hline Total & $23(46 \%)$ & $27(54 \%)$ & $50(100 \%)$ & \\
\hline
\end{tabular}

Berdasarkan Tabel 5 menunjukkan bahwa responden yang memiliki imunisasi TT lengkap paling banyak pada usia 20-35 tahun (30\%). Bertambahnya umur seseorang, maka dalam berpikir dan bekerja akan lebih matang, hal ini sebagian dari pengalaman dan kematangan jiwa. ${ }^{5}$

Pada usia madya (20-35 tahun), ibu hamil akan lebih berperan aktif dalam masyarakat dan kehidupan sosial serta lebih banyak melakukan persiapan demi suksesnya upaya penyesuaian dirinya menuju usia tua, selain itu usia madya akan lebih banyak menggunakan waktunya untuk membaca. Kemampuan intelektual, pemecahan masalah, dan kemampuan verbal seseorang pada usia ini semakin meningkat dan tidak terjadi kecenderungan penurunan. ${ }^{6}$

Berdasarkan Tabel 5 hasil uji chi square menunjukkan nilai signifikansi $\mathrm{p}=0,004<$ alpha $=0,05$, yang berarti bahwa ada hubungan antara umur dengan kelengkapan imunisasi TT di BPM Dyah Widya Susilowati Ngemplak Boyolali. Perilaku dapat terbentuk diawali dengan adanya pengetahuan kemudian sikap. Umur mempengaruhi daya tangkap dan pola pikir seseorang. ${ }^{6}$

Hasil penelitian ini didukung oleh penelitian yang menyatakan bahwa hasil uji statistic Chi Square didapatkan nilai $\mathrm{p}$ value $=0,000$ berarti lebih kecil dari alpha $<0,005$. Jadi dapat disimpulkan bahwa ada hubungan yang bermakna 
antara umur ibu dengan kelengkapan imunisasi TT pada ibu hamil. ${ }^{7}$

Ibu dengan usia produktif merupakan ibu dalam kelompok umur produktif, dimana seseorang dituntut untuk mempersiapkan dan mengatur segala kebutuhan khususnya dalam menjaga kesehatan diri dan bayi yang dikandungnya termasuk mengikuti imunisasi tetanus toksoid ketika ibu hamil. ${ }^{6}$

Tabel 6. Hubungan Gravida dengan Kelengkapan Imunisasi TT Pada Ibu Hamil di BPM Dyah Widya Susilowati Ngemplak Boyolali

\begin{tabular}{lcccc}
\hline \multicolumn{5}{c}{ Kelengkapan } \\
Imunisasi_TT & & \\
Gravida & Ya & Tidak & & P \\
& Lengkap & Lengkap & Total & \\
\hline Primigravida & 22 & 3 & 25 & 0,000 \\
& $(44 \%)$ & $(6 \%)$ & $(50 \%)$ & \\
Multigravida & 1 & 19 & 20 & \\
& $(2 \%)$ & $(38 \%)$ & $(40 \%)$ & \\
Grandemulti & 0 & 5 & 5 & \\
gravida & $(0 \%)$ & $(10 \%)$ & $(10 \%)$ & \\
\hline Total & $23(46 \%)$ & $27(54 \%)$ & $50(100 \%)$ & \\
\hline
\end{tabular}

Berdasarkan Tabel 6 menunjukkan bahwa responden yang memiliki imunisasi TT lengkap paling banyak pada primigravida (44\%). Berdasarkan Tabel 5 hasil uji chi square menunjukkan nilai signifikansi $\mathrm{p}=0,000$ $<$ alpha $=0,05$, yang berarti bahwa ada hubungan antara gravida dengan kelengkapan imunisasi TT di BPM Dyah Widya Susilowati Ngemplak Boyolali.

Ibu hamil pertama kali akan lebih mempersiapkan diri dalam perawatan kehamilan dikarenakan tekanan dan kecemasan akan kondisi diri serta bayinya sehingga rasa memiliki dan tanggungjawab yang lebih besar untuk melakukan imunisasi TT. Meskipun hal ini bergantung pada idividu ibu hamil itu sendiri. Sedangkan pada ibu hamil kedua atau lebih, akan cenderung kurang memperhatikan kehamilan atau sebaliknya. $^{8}$

Ibu hamil yang mendapatkan suntikan tetanus toksoid sesuai anjuran petugas kesehatan, maka dapat memberi perlindungan terhadap tetanus pada ibu dan bayi. ${ }^{9}$

Hasil penelitian ini juga didukung oleh penelitian yang menunjukkan hasil analisis statistik dengan menggunakan uji chi-square antara paritas dengan status kematian bayi penderita TN diperoleh nilai $\mathrm{p}=0,034(\mathrm{p}<\alpha)$ yang bermakna terdapat hubungan antara tingkat paritas dengan status kematian bayi penderita TN di Provinsi Jawa Timur pada tahun 2014-2016. ${ }^{10}$

Tabel 7. Hubungan Pendidikan dengan Kelengkapan Imunisasi TT Pada Ibu Hamil di BPM Dyah Widya Susilowati Ngemplak Boyolali

\begin{tabular}{lcccc}
\hline \multirow{5}{*}{ Kelengkapan } & & \\
Pendidikan & Ymunisasi_TT & & \\
& Lengkap & Lengkap & Total & \\
\hline Pendidikan & 5 & 10 & 15 & 0,192 \\
Dasar & $(10 \%)$ & $(20 \%)$ & $(30 \%)$ & \\
Pendidikan & 14 & 16 & 30 & \\
Menengah & $(28 \%)$ & $(32 \%)$ & $(60 \%)$ & \\
Pendidikan & 4 & 1 & 5 & \\
Tinggi & $(8 \%)$ & $(2 \%)$ & $(10 \%)$ & \\
\hline Total & $23(46 \%)$ & $27(54 \%)$ & $50(100 \%)$ & \\
\hline
\end{tabular}

Pendidikan dapat mempengaruhi sesorang termasuk juga perilaku seseorang akan pola hidup terutama dalam memotivasi untuk sikap berperan serta dalam pembangunan, pada umumnya makin tinggi pendidikan seseorang makin mudah menerima informasi. ${ }^{8}$

Berdasarkan Tabel 7 menunjukkan bahwa responden yang memiliki imunisasi TT lengkap paling banyak pada Pendidikan Menengah (28\%), selain itu pada pendidikan tinggi sebagian besar memiliki imunisasi TT lengkap sebanyak 4 responden dari total 5 responden. Berdasarkan Tabel 5 hasil uji chi square menunjukkan nilai signifikansi $\mathrm{p}=0,192>$ alpha $=0,05$, yang berarti bahwa terdapat tidak ada hubungan antara pendidikan dengan kelengkapan imunisasi TT di BPM Dyah Widya Susilowati Ngemplak Boyolali. 
Hasil penelitian ini didukung penelitian Sokhiyatun, dimana nilai p $>0,05$ yaitu 0,737 sehingga Ha ditolak Ho diterima. Dari hasil tersebut dapat disimpulkan "Tidak ada hubungan antara pendidikan dengan kelengkapan imunisasi TT". Proporsi anak dari ibu umur 20-34 tahun, ibu yang tinggal di perkotaan dan ibu dengan pendidikan menengah ke atas lebih besar kemungkinannya untuk terlindung dari tetanus daripada ibu-ibu lain. ${ }^{8}$

Tabel 8. Hubungan Umur, Gravida dan Pendidikan dengan Kelengkapan Imunisasi TT Pada Ibu Hamil di BPM Dyah Widya Susilowati Ngemplak Boyolali

\begin{tabular}{cccccc}
\hline \multirow{2}{*}{ Variabel } & Wald & $\mathrm{P}$ & \multicolumn{2}{c}{ OR } & \multicolumn{2}{c}{$\begin{array}{c}\text { ER C.I for } \\
\text { EXP(B) }\end{array}$} \\
& & & $(\mathrm{EXP}\{\mathrm{B}\})$ & Lower & Upper \\
\hline Umur & 0,005 & 0,946 & 0,912 & 0,064 & 13,024 \\
Gravida & 11,836 & 0,001 & 187,835 & 9,515 & 3707,849 \\
Pendidikan & 0,410 & 0,522 & 1,884 & 0,271 & 13,114 \\
\hline \multicolumn{4}{l}{ Nagelkerke R Square $=0,773$} \\
& nilai p value Chi-Square sebesar 0,000 \\
\hline
\end{tabular}

Berdasarkan Tabel 8 menunjukkan hasil Analisis multivariat dengan menggunakan uji regresi logistik binary untuk mengetahui hubungan variabelvariabel bebas yang mempengaruhi Kelengkapan imunisasi TT meliputi umur, gravida dan pendidikan dengan menggunakan Uji Statistik SPSS versi 17 menunjukkan data bahwa menerima $\mathrm{Ha}$ atau menolak $\mathrm{H} 0$ atau yang berarti ada hubungan signifikan secara simultan umur, gravida dan pendidikan terhadap Kelengkapan imunisasi TT dengan nilai Sig $0,000<$ alpha 0,05. Variabel independen yang ada hubungan bermakna terhadap variabel dependen adalah variabel gravida $(\mathrm{p}=0,001)$ memiliki $\mathrm{p}<0,05$. Nilai OR $(\operatorname{EXP}\{B\})$ pada variabel gravida $=187,835$ yang artinya primigravida paling bermakna berhubungan terhadap kelengkapan imunisasi TT pada ibu hamil dibandingkan multigravida dan grandemultigravida sebesar 187,835 kali.

Respon ibu hamil terhadap stimulus yang berkaitan dengan sakit dan penyakit, dalam hal ini kelengkapan imunisasi TT merupakan perilaku pencegahan penyakit (health prevention behavior). ${ }^{5}$

Hasil penelitian ini sejalan dengan penelitian lainnya yang menyatakan bahwa ada hubungan antara usia responden dengan pelaksanaan imunisasi Tetanus Difteri di wilayah kerja Puskesmas Kecamatan Burneh Tahun 2016 ( $\mathrm{p}=0,000)$; ada hubungan antara tingkat pendidikan dengan pelaksanaan imunisasi Tetanus Difteri di wilayah kerja Puskesmas Kecamatan Burneh Tahun $2016(\mathrm{p}=0,002)$. Ada hubungan antara Gravida dengan Kelengkapan Imunisasi TT di wilayah kerja Puskesmas Tahunan Jepara $(\mathrm{p}=0,002) .{ }^{4,8}$

Hasil penelitian ini juga didukung oleh penelitian yang menyebutkan bahwa nilai signifikan $\mathrm{p}$ value $=0,000<$ $\alpha=0,05$, yang berarti bahwa terdapat hubungan antara pendidikan dengan status imunisasi tetanus toxoid pada ibu hamil di wilayah kerja Puskesmas Kecamatan Kao Kabupatan Halmahera Utara. ${ }^{11}$

Untuk melihat kemampuan variabel independen dalam menjelaskan variabel dependen, digunakan nilai $C o x$ dan Snell $R$ Square dan Nagelkerke $R$ Square yang ditunjukkan pada Tabel 8 . Nilai Nagelkerke $R$ Square sebesar 0,773 dan Cox \& Snell R Square 0,578, yang menunjukkan bahwa kemampuan variabel umur, gravida dan pendidikan dalam menjelaskan Kelengkapan imunisasi TT adalah sebesar 77,8\%, sedangkan sisanya sebesar $22 \%$ dijelaskan oleh variabel lain di luar model yang menjelaskan variabel dependen. Faktor-faktor yang mempengaruhi terbentuknya perilaku dalam hal kelengkapan imunisasi TT pada ibu hamil ada dua yakni faktor eksternal dan faktor internal. Faktor intern mencakup pengetahuan, kecerdasan, persepsi, emosi, motivasi dan sebagainya yang berfungsi untuk mengolah rangsangan dari luar. Sedangkan faktor ekstern meliputi lingkungan sekitar, baik fisik maupun non fisik seperti iklim, manusia, sosial ekonomi, kebudayaan dan sebagainya. ${ }^{5}$ Kelengkapan imunisasi TT dipengaruhi 
oleh Faktor gravida, dimana gravida dapat dijelaskan sebagai proses belajar atau perubahan perilaku yang dihasilkan dari praktik-praktik dalam lingkungan kehidupan. $^{5}$

Untuk mencegah terjadinya tetanus neonatorum, ibu hamil harus mendapat imunisasi TT. Pada saat kontak pertama, ibu hamil diskrining satus imunisasi $\mathrm{T}$ nya. Pemberian imunisasi TT pada ibu hamil disesuaikan dengan status imunisasi $\mathrm{T}$ ibu saat ini. Ibu hamil minimal memiliki status imunisasi dengan status imunisasai T2 agar mendapatkan perlindungan infeksi tetanus. Ibu hamil dengan satus imunisaai T5 (long life) tidak perlu diberikan imunisasi TT lagi. Hal ini mengacu pada pedoman pemberian imunisasi TT bahwa tidak mempunyai interval maksimal, hanya terdapat interval minimal sehingga bisa diketahui lama perlindungannya. ${ }^{12}$

\section{Kesimpulan}

Berdasarkan hasil penelitian menunjukkan adanya hubungan antara umur, gravida dan pendidikan dengan kelengkapan imunisasi Tetanus Toxoid pada ibu hamil di BPM Dyah Widya Susilowati Ngemplak Boyolali. Bagi ibu hamil dan keluarga diharapkan mempersiapkan seemua kehamilan dengan baik serta teratur melakukan pemeriksaan kehamilan agar status imunisasi TT terpenuhi untuk memberikan perlindungan terhadap tetanus pada ibu dan bayi. Bagi tenaga kesehatan, lebih meningkatkan skrining imunisasi TT pada ibu hamil dan melakukan pencatatan yang efektif dan membuat dokumentasi yang lebih baik untuk mempermudah evaluasi Status imunisasi TT ibu hamil. Serta perlunya konseling rutin dan lebih dini sejak perencanaan kehamilan mengenai Imunisasi Tetanus Toxoid pada ibu hamil.

\section{Daftar Pustaka}

[1] Kementerian Kesehatan RI. 2012. Buletin Jendela Data dan Informasi Kesehatan "Eliminasi Tetanus Maternal Neonatal”. http://www.depkes.go.id/downlo ad.php? file $=$ download/pusdatin/ buletin/buletin-mnte.pdf.

[2] Kabupaten Boyolali. Profil Kesehatan Kabupaten Boyolali 2015.

http://www.depkes.go.id/resourc es/download/profil/PROFIL_KA B KOTA 2015/3309 Jateng K ab_Boyolali_2015.pdf, 2016

[3] Astuti, Sri, Ari IS, Rani N, Ariyati M. 2017. Asuhan Ibu dalam Masa Kehamilan. Bandung: Erlangga.

[4] Triratnasari, Diah. 2017. Faktor Yang Berhubungan Dengan Pelaksanaan Imunisasi Tetanus Difteri Pada Ibu Hamil. Jurnal Berkala Epidemiologi Volume 5 Nomor 3 September 2017 hlm 325$337 . \quad$ https://ejournal.unair.ac.id/JBE/article/vi ewFile/5435/4270

[5] A.Wawan dan Dewi M. 2010. Teori dan Pengukuran Pengetahuan, Sikap, Dan Perilaku Manusia. Yogyakarta: Nuha Medika

[6] Safitri, Ria. 2016. Hubungan Pengetahuan Ibu Hamil Dengan Partisipasi Dalam Melakukan Imunisasi Tetanus Toksoid Di Puskesmas Gondang Kabupaten Sragen. http://eprints.ums.ac.id/44860/1/ NASKAH \%20PUBLIKASI.pdf

[7] Yunica, Joyce Angela. 2015. Hubungan Antara Pengetahuan dan Umur dengan Kelengkapan Imunisasi Tetanus Toxoid (TT) pada Ibu Hamil di Desa Sungai Dua Kecamatan Rambutan Kabupaten Banyuasin Tahun 2014. Jurnal Kedokteran dan Kesehatan, Volume 2 Nomor 1, Januari 2015, hlm 93-98. https://ejournal.unsri.ac.id/index.ph $\mathrm{p} / \mathrm{jkk} /$ article/view/2538

[8] Sokhiyatun, Luluk Hidayah, Arinda Setiyani. 2015. Hubungan Karakteristik Ibu Hamil Dengan Kelengkapan Imunisasi Tetanus Toksoid Di Wilayah Kerja Puskesmas Tahunan Jepara. 
https://jurnal.unimus.ac.id/index. php/jur bid/article/view/1811

[9] Kemenkes Kesehatan Republik Indonesia. 2015. Buku Kesehatan Ibu dan Anak. Jakarta: Kementerian Kesehatan dan JICA (Japan International Cooperation Agency) 1997.

[10] Sari, Selvy Novita. 2017. Analisis Faktor Risiko Kematian Bayi Penderita Tetanus Neonatorum Di Provinsi Jawa Timur. Jurnal Berkala Epidemiologi Volume 5 Nomor 2, Mei 2017, hlm 195-206. https://e-

journal.unair.ac.id/JBE/article/vi ewFile/4786/3880

[11]Djinimangale, Sefnad dan Sarah W, Novie R. 2017. Analisis Antara Pengetahuan, Pendidikan dan Dukungan Petugas Kesehatan Dengan Status Imunisasi Tetanus Toxoid Pada Ibu Hamil Di Wilayah Kerja Puskesmas Kecamatan Kao Kabupaten Halmahera Utara.Jurnal Paradigma Sehat Volume 5 nomor 3, 2017 https://ejournalhealth.com/index.ph p/paradigma/article/view/592

[12]Kemenkes Kesehatan Republik Indonesia. 2013. Pedoman Pelayanan Antenatal Terpadu Edisi Kedua. Jakarta: Kementerian Kesehatan, Direktorat Jenderal Bina Gizi dan KIA, dan Direktorat Bina Kesehatan Ibu. 
